\title{
Climate Change Effects on Supply and Demand of Rice in India
}

\author{
Chih-min HUNG ${ }^{1,2}$, Lin ZHOU ${ }^{1,3}$ and Jun FURUYA ${ }^{1 *}$ \\ ${ }^{1}$ Social Sciences Division, Japan International Research Center for Agricultural Sciences \\ (Tsukuba, Ibaraki 305-8686, Japan)
}

\begin{abstract}
This study was conducted to clarify how climate change is expected to affect the demand and supply of rice in India, an important rice-producing and rice-consuming nation. The method, a supply-demand model, includes six functions: yield, area, export, stock change, demand, and price linkage. To reflect topographic and climate diversity, these analyses use state data instead of national data. Results for rice supply show the benefits and shortcomings of temperature, precipitation, and solar radiation as determined by location and season. Scenario analyses that combine the three dimensions of Representative Concentration Pathways (RCP) and Shared Socioeconomic Pathways (SSP) scenarios elucidate the future supply and demand of rice, revealing that rice production and per-capita consumption can be boosted most if India undergoes conventional development. Alternatively, a fragmented society that faces higher challenges regarding mitigation and adaptation is expected to engender lower rice yields. To maintain sufficient rice production, the government must undertake social development projects and adequately address climate change-related difficulties.
\end{abstract}

Discipline: Agricultural economics

Additional key words: temperature, precipitation, solar radiation, socioeconomic scenarios

\section{Introduction}

According to the 2016 Global Hunger Index (von Grebmer et al. 2016), the highest hunger levels are found in Sub-Saharan Africa and South Asia. In South Asia, India has exhibited the worst results for several decades. Moreover, India is expected to overtake China in 2 in becoming the world's most populous nation by 2022, con according to the 2015 revision of World Population pror Prospects reported by the United Nations. Under such circumstances, food security has brought great concern
in India. Kumar et al. (2009) have issued a warning of that current trends in production indicate that domestic production will have difficulty satisfying future food grain demand.

Among all foodgrains, rice is the most consumed in India (Directorate of Economics and Statistics 2015). Data from the Food and Agriculture Organization Corporate Statistical Database (FAO-STAT) also show that the rice production and cultivation areas are greater than those of other crops. And since 2012, India has overtaken Thailand as the world's largest rice exporter. In 2013, India's share of world rice exports was $30.1 \%$ and subject to wide fluctuations according to domestic production. The share of total exports to the total production of rice in the world was only $6.0 \%$ in 2013. Therefore, the world rice market is relatively small compared to the domestic rice market, and India's rice production strongly affects the world food market.

Rice in India is grown mainly in irrigated and rainfed areas. In the total rice area, the respective percentages of irrigated, rain-fed, and flood-prone rice areas are about $49.5 \%, 45.9 \%$ and $4.6 \%$, respectively (Directorate of Rice Development 2014). In particular, rice production in rain-fed areas is highly sensitive to climate conditions. Goswami et al. (2006) detected two abnormal climatic phenomena in India: (1) considerable increases in the frequency and magnitude of extreme rain events, and (2) marked decreases in the frequency of moderate events over central India during the

\section{Present addresses:}

${ }^{2}$ Department of Economics, McGill University (Montreal, Quebec H3A 2T7, Canada)

${ }^{3}$ Institute of Food and Nutrition Development, Ministry of Agriculture (Beijing 100081, China)

*Corresponding author: e-mail furuya@affrc.go.jp

Received 21 December 2016; accepted 25 October 2017 
monsoons of 1951-2000.

In considering both population growth and climate change, one might be intrigued to clarify the influences of climate change on rice, the largest produced and most consumed crop in India, Moreover, future forecasts of the demand and supply of rice are clouded by uncertainty that climate change presents.

Several approaches have been adopted to analyze the effects of climate change on agriculture. Pohit (1997) analyzed four agriculture sectors (paddy, wheat, grains, non-grain crops) and six non-agricultural sectors using a Computable General Equilibrium (CGE) model. The results showed that, except for wheat and non-grain crops, carbon dioxide fertilization effects decreased in India. Sulser et al. (2010) combined precipitation and irrigation with the International Model for Policy Analysis of Agricultural Commodities and Trade (IMPACT), which is a world food model of the International Food Policy Research Institute (IFPRI). They detected declining trends in water productivity for cereal production in the Ganges and Nile river basins and in net trade (exports minus imports) for cereal in India until 2050. In 2000, the Intergovernmental Panel on Climate Change (IPCC) issued the Special Report on Emissions Scenarios (SRES), and these scenarios were used to project the future impacts of climate change on food grains. Furuya et al. (2009) explored the influence of global warming on the world food market under the SRES using the International Food and Agricultural Policy Simulation Model (IFPSIM), which consists of yield, area, demand, export, import, stock, and price linkage functions. The results for Indian rice under the $\mathrm{A} 1 \mathrm{~B}, \mathrm{~B} 1, \mathrm{~A} 2$, and B2 ${ }^{1)}$ scenarios in the SRES revealed a decrease in production and an increase in the growth rate of consumption.

From a review of earlier literature describing climate change effects on food grain production in India, we noted the wide use of national data. Few reports of the relevant literature describe studies using state or regional data. Kumar et al. (2004) clarified the influence of monsoon rainfall on the production of five major crops based on state-level statistics. Soora et al. (2013) adopted the SRES scenarios to predict the impact of climate change on rain-fed rice yields in five regions covering several states. Given India's diverse topography and climate, conducting analyses using state data is expected to reflect actual conditions better than when using national data. Therefore, this study divides all territories into 28 districts and provides a supply-demand model to assess the particular influences of climate change on the rice market.

The purpose of this study is to conduct an economic evaluation of the impacts of climate change on rice production in each state in India and on rice supply and demand for the whole country, and to clarify the regions that the government needs to focus on for implementing countermeasures. It is still fresh in our memory that the export ban on rice by the Indian government worsened the already tight food supply in 2007, which was a particularly poor harvest year. The development of an economic model that can evaluate the regional impacts of climate change is very important for devising countermeasures.

Temperature and precipitation are often examined (e.g. Cabas et al. 2010) to estimate rice yield. Solar radiation plays an important role in rice yield, but is rarely considered. Even though earlier reports of the literature tend to disregard climatic factors for measuring the areas of rice, Khan \& Zaman (2010) present evidence of a relation between rainfall and wheat production. Consequently, we include temperature, precipitation, and solar radiation in the yield function, and incorporate precipitation into the area functions.

To project the effects of climate change on crops, some studies have specifically emphasized socioeconomic factors such as population growth rate and income growth (Kumar et al. 2012, 2014). In contrast to such socioeconomic investigations, we forecast the supply and demand of rice based on representative concentration pathways and climate policy assumptions. Two steps exist for this study. First, we elucidate the influence of climate change on the supply, demand, and price of rice in India. At the second stage, we project the tendencies in several probable scenarios based on a combination of Representative Concentration Pathways (RCP) and Shared Socioeconomic Pathways (SSP) scenarios.

\section{Model}

\section{Rice production}

Rice cultivation in India has three seasons: Rabi, pre-Kharif, and Kharif, corresponding to the summer, autumn, and winter harvesting seasons, respectively. Figure 1 presents the rice cropping calendar. Since 1981, the DES (2017) has integrated data of pre-Kharif (autumn rice) into those of Kharif (winter rice). For the continuity of data, we aggregate autumn and winter rice as Kharif.

\section{Supply and demand model of rice}

To investigate the influences of climate change on the supply and demand of rice, we use the supply and demand model of rice based on the model of Furuya et al. (2010). India's extensive territory encompasses various topographical features and climates. For this reason, we modified the original model and used state data instead 


\begin{tabular}{|c|c|c|c|c|c|c|c|c|c|c|c|c|}
\hline Seasons & Jan & Feb & Mar & Apr & May & Jun & Jul & Aug & Sep & Oct & Nov & Dec \\
\hline Summer & \multicolumn{2}{|c|}{ Sowing } & \multicolumn{6}{|c|}{ Harvesting } & & \multicolumn{3}{|c|}{ Sowing } \\
\hline \multirow{2}{*}{ Autumn } & & & \multicolumn{6}{|c|}{ Sowing } & & & & \\
\hline & & & & & & \multicolumn{7}{|c|}{ Harvesting } \\
\hline Winter & \multicolumn{4}{|c|}{ Harvesting } & & & \multicolumn{3}{|c|}{ Sowing } & & \multicolumn{2}{|c|}{ Harvesting } \\
\hline
\end{tabular}

Fig. 1. Rice cropping calendar for India.

Source: Directorate of Economics and Statistics, Ministry of Agriculture, New Delhi

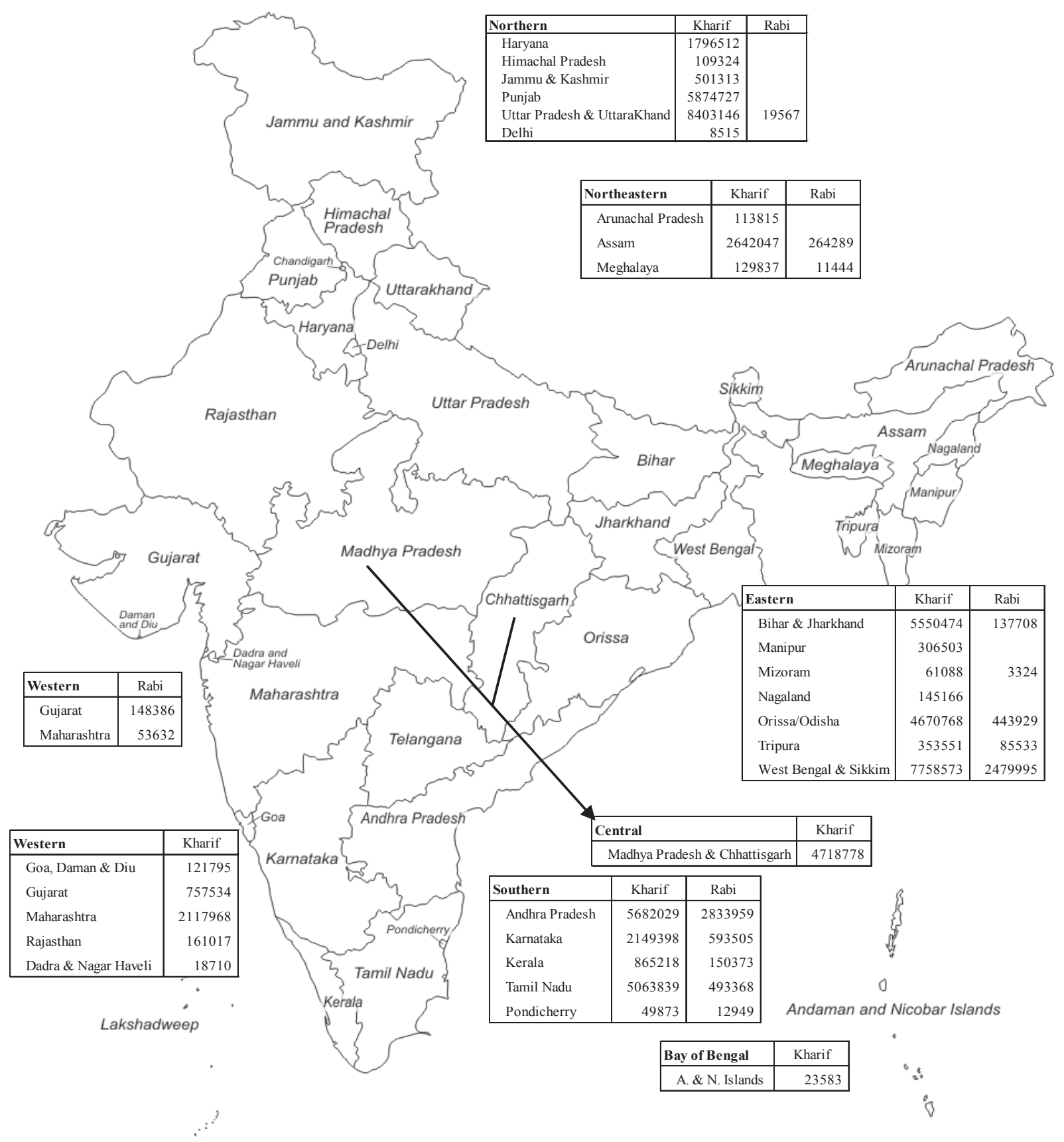

Fig. 2. Indian states and their average production (in tons) of Kharif and Rabi during 1969-2009.

(Source of map: http://www.d-maps.com/carte.php?num_car=24855\&lang=en) 
of provincial data. Although mergers and splits have occurred among Indian states and union territories during the period of analyses, 28 regions are divided based on the divisions of 1969 (see Fig. 2).

This model consists of the following six functions.

(1) Yield function

$$
\begin{gathered}
Y K_{i, t}=\alpha_{y k}+\beta_{y k 1} T M P_{i, t m}+\beta_{y k 2} P R C_{i, t m}+\beta_{y k 3} S R A_{i, t m}+\varepsilon_{y k} \\
Y R_{i, t}=\alpha_{y r}+\beta_{y r 1} T M P_{i, t m}+\beta_{y r 2} P R C_{i, t m}+\beta_{y r 3} S R A_{i, t m}+\varepsilon_{y r}
\end{gathered}
$$

In the equations above, $Y K$ stands for the yield of Kharif per hectare, $Y R$ signifies the yield of Rabi per hectare, $T M P$ denotes the temperature in degrees Celsius $\left({ }^{\circ} \mathrm{C}\right)$, $P R C$ represents precipitation in millimeters, $S R A$ denotes solar radiation in megajoules per day, $\varepsilon$ is an error term, and the subscripts $i, t$, and $m$ represent the state, year, and month, respectively.

(2) Area function

$$
\begin{aligned}
& A K_{i, t}=\alpha_{a k}+\beta_{a k 1} A K_{i, t-1}+\beta_{a k 2} F C_{t-1}+\beta_{a k 3} P R C_{i, t m}+\varepsilon_{a k} \\
& A R_{i, t}=\alpha_{a r}+\beta_{a r 1} A R_{i, t-1}+\beta_{a r 2} F C_{t-1}+\beta_{a r 3} P R C_{i, t m}+\varepsilon_{a r}
\end{aligned}
$$

Therein, $A K$ signifies the harvested area of Kharif in hectares, $A R$ denotes the harvested area of Rabi in hectares, and $F C$ represents the real farm price defined as $F P /(C P I / 100)$, where $F P$ stands for the farm price of rice (rupees per ton) and $C P I$ denotes the consumer price index.

(3) Paddy production

$$
Q P R_{t}=\sum_{i} Y K_{i, t} A K_{i, t}+\sum_{i} Y R_{i, t} A R_{i, t}
$$

In the equation above, $Q P R$ represents the paddy production.

(4) Production of milled rice

$$
Q_{t}=0.667 \times Q P R_{t}
$$

$Q$ represents the production of milled rice. The paddy to rice conversion rate is 0.667 , based on estimation by FAO-STAT.

(5) Export function

$$
E X P_{t}=\alpha_{e}+\beta_{e 1} Q_{t}+\beta_{e 2} W E G_{t}+\beta_{e 3} R C_{t}+\varepsilon_{e}
$$

Therein, EXP is the export volume of milled rice. WEG is defined as $(W P \times E X R) /(G D P D / 100)$, which denotes the real world price of rice in Indian rupees. Here, $W P$ is the world price of rice in US dollars, represented by the Thai $5 \%$ broken rice, f.o.b. Bangkok, and EXR is the rupee US dollar exchange rate. GDPD is the GDP deflator. The definition of $R C$ is $R P R /(C P I / 100)$, which denotes the real retail price of rice, where $R P R$ is the retail price of rice.

(6) Stock change function

$$
S T C_{t}=\alpha_{s}+\beta_{s 1}\left(Q_{t}-Q_{t-1}\right)+\beta_{s 2}\left(R C_{t}-R C_{t-1}\right)+\varepsilon_{s}
$$

In that equation, STC is the annual change in stock of milled rice, as calculated by subtracting the beginning stock from ending stock.

(7) Supply of rice

$$
Q S_{t}=Q_{t}+I M P_{t}-E X P_{t}-S T C_{t}-\left(F D_{t}+S D_{t}+W S T_{t}+P R O C_{t}\right)
$$

Therein, $Q S$ signifies the total supply of rice, IMP denotes the import volume of milled rice, $F D$ refers the quantity of milled rice for feeding livestock and poultry, $S D$ represents the amounts of milled rice set aside for sowing, planting, and reproduction purposes, WST denotes the amount of milled rice lost through wastage between the level at which production is recorded and the household, and PROC stands for the quantities of processing for food. The sum of variables enclosed in parentheses denotes the domestic utilization of milled rice.

(8) Per-capita consumption

$$
Q D_{t}=Q S_{t} / P O P_{t}
$$

$Q D$ is the per-capita consumption of milled rice. $P O P$ represents the population.

(9) Demand function

$$
Q D_{t}=\alpha_{q}+\beta_{q 1} R C_{t}+\beta_{q 2} G P_{t}+\varepsilon_{q}
$$

Therein, GP is defined as the real gross domestic product (GDP) divided by POP. Here, the real GDP is GDP converted to 2005 constant international dollars using purchasing power parity rates. Here, other substitutes are not considered because the cross price elasticity of demand of rice for other cereals and food is inelastic in India (Kumar et al. 2011).

(10) Price linkage function

$$
F P_{t}=\alpha_{f}+\beta_{f 1} R P R_{t}+\varepsilon_{f}
$$

The retail price and farm price are equilibrium prices determined as the quantity demanded equal to the quantity supplied. In other words, both are marketclearing prices.

We use the data of each state to estimate the areas and yields of Rabi and Kharif separately. Farm prices and precipitation affect the harvested areas of rice. The climate variables are exogenous and also affect the rice 
yield.

Figure 3 shows the flowchart of supply and demand for rice econometric model for India. Total production is the sum of Rabi and Kharif production. Domestic utilization is defined as the sum of feed, seed, waste, processing for food, and other forms of utilization. Supply is influenced by total production, domestic utilization, stock changes, and the volumes of exports and imports. Demand is affected by the population, gross domestic product, consumer price index, and retail prices. Retail prices are determined when supply and demand reach equilibrium. The movements of retail prices are transferred to farm price through the price linkage function and the farm price affects next year's supply. In this sector, the exchange rate, world price, imports, population, and GDP are exogenous variables.

\section{Data}

The estimation period was 1969-2009, for which all data are available. The DES (2017) is the source of yield, harvested area, and production data. The data of $C P I$, $E X R, G D P D$, real $G D P$, and $P O P$ are obtainable from the WDI (2017). $R P R$ is acquired from the International Rice Research Institute ${ }^{3}$. WP is data of the IMF (2017). The following data were obtained from FAO-STAT (2017): FP, EXP, STC, IMP, FD, SD, WST, and PROC. Observations of climate variables, specifically temperature, precipitation, and solar radiation, were compiled by the CRU (2017).

The forecast period was set as 2010-2060 for two reasons. One is that India's population is expected to peak at 1.718 billion in 2060, after which it will decline, according to the population projection released by the United Nations Population Division (UNPD) in 2011. Another reason is that the atmospheric $\mathrm{CO}_{2}$ concentration, a factor affecting climate change, is projected to reach its zenith in 2060 (Tollefson 2015). The projections of POP and real $G D P$ are calculated by the International Institute for Applied Systems Analysis (IIASA). Forecast data of climate variables were estimated from the Model for Interdisciplinary Research on Climate (MIROC5), based on RCPs. The assumptions of other predictive variables are as follows: $G D P D$ was estimated from the average growth rate during 1989-2009; CPI was estimated from the average growth rate during 2003-2009; IMP was estimated from the average growth rate of 1996-2008; $R P R$ was estimated from the average growth rate during 1971-2003; STC was estimated from the average growth rate of 1990-2009; PROC, FD, SD, and WST were estimated from their individual average growth rates of 1993-2007; EXR was estimated from the average growth rate during 1971-2007; and WP was estimated from the average growth rate during 1983-2009. Each period we chose was most representative of the tendency of its variable.

\section{Empirical analysis}

We initially conducted tests of stationarity to ascertain whether differencing variables are necessary. If necessary, we will then modify these variables and proceed to estimate the functions presented above.

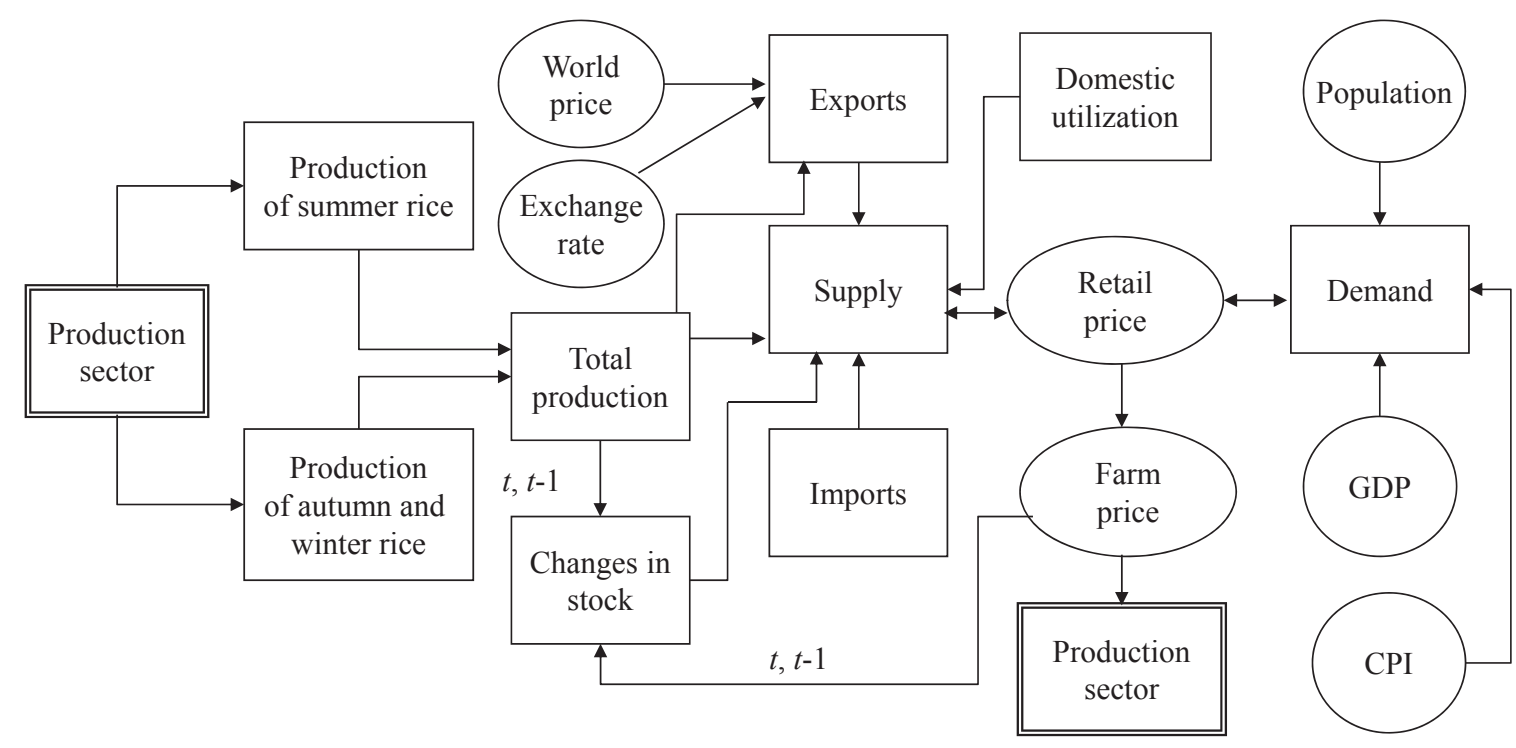

Fig. 3. Flowchart showing supply and demand of the rice econometric model for India (based on Furuya et al. 2010). 


\section{Tests of stationarity}

To avoid the problem of spurious regression, we first apply the augmented Dickey-Fuller (ADF) tau test to examine the stationarity of all variables. The optimal lag length is selected using the Akaike Information Criterion (AIC). Engle-Granger tests are applied in the next step if variables have unit roots. Even though the variables are non-stationary, the existence of cointegration signifies a stable long-run equilibrium relation. The linear combination is both stationary and predictable.

Results show that most variables in the functions of yield, area, and exports have unit roots. Cointegration relations are absent from these functions. Although few variables are stationary, we transform all variables into first-order differences in an attempt to create uniform estimation methods that are applicable to each state. The $p$-value of each transformed variable is less than 0.01 , except the first-order difference of $W E G$, the $p$-value of which is $0.01-0.05$. The result implies the stationarity of these variables (Appendix A). Accordingly, we transform equations (1)-(4) and (7) as shown below.

$$
\begin{aligned}
& \Delta Y K_{i, t}=\alpha_{y k}^{\prime}+\beta_{y k 1}^{\prime} \Delta T M P_{i, t m}+\beta_{y k 2}^{\prime} \Delta P R C_{i, t m}+\beta_{y k 3}^{\prime} \Delta S R A_{i, t m}+v_{y k}\left(1^{\prime}\right) \\
& \Delta Y R_{i, t}=\alpha_{y r}^{\prime}+\beta_{y r 1}^{\prime} \Delta T M P_{i, t m}+\beta_{y r 2}^{\prime} \Delta P R C_{i, t m}+\beta_{y r 3}^{\prime} \Delta S R A_{i, t m}+v_{y r} \\
& \Delta A K_{i, t}=\alpha_{a k}^{\prime}+\beta_{a k 1}^{\prime} \Delta A K_{i, t-1}+\beta_{a k 2}^{\prime} \Delta F C_{t-1}+\beta_{a k 3}^{\prime} \Delta P R C_{i, t m}+v_{a k} \\
& \Delta A R_{i, t}=\alpha_{a r}^{\prime}+\beta_{a r 1}^{\prime} \Delta A R_{i, t-1}+\beta_{a r 2}^{\prime} \Delta F C_{t-1}+\beta_{a r 3}^{\prime} \Delta P R C_{i, t m}+v_{a r} \\
& \Delta E X P_{t}=\alpha_{e}^{\prime}+\beta_{e 1}^{\prime} \Delta Q_{t}+\beta_{e 2}^{\prime} \Delta W E G_{t}+\beta_{e 3}^{\prime} \Delta R C_{t}+v_{e}
\end{aligned}
$$

In these equations, $\Delta$ represents the difference between one period and the prior period. The stock change function is not modified due to the existence of stationary variables. Moreover, the variables of the demand and price linkage functions have unit roots. Therefore, Engle-Granger tests are applied. The $p$-values are 0.083 and 0.018 , respectively, which verify the existence of cointegration and signify steady long-run equilibrium relations. Therefore, both functions are also unchanged.

\section{Estimated results of functions}

\section{(1) Yield function}

Table 1 and Table 2 depict the relations between the rice yield and temperature. Higher temperatures generally decrease the yields of rice after May because the average temperature is sufficiently high so that overly hot weather hinders growth. Although the weather turns cool after September, high temperatures are still disfavored due to the simultaneous decrease in precipitation. However, the reverse results are clear in a few states such as Arunachal Pradesh, Jammu, and Kashmir, which are located at extremely high elevations, where warmer weather seems to favor rice growth.

The results also show that more precipitation tends to boost the yield of Kharif during April-September, when the monthly average temperature (higher than $26^{\circ} \mathrm{C}$ ) is higher than those of other months. It signifies that ample precipitation is favorable for growth of Kharif in hotter seasons. Nevertheless, the relation is reversed in November, probably due to greater decreases in temperature and solar radiation during October-November than in any other period. Therefore, precipitation becomes a negative factor. We failed to find the same tendency for that of Rabi. More precipitation only elevates the yield of Rabi in the northern and northeastern regions where average temperatures are the two lowest (about $20^{\circ} \mathrm{C}$ and $21^{\circ} \mathrm{C}$ ). The data also point out that more sufficient solar radiation not only benefits the yield of Kharif during January-April and in November, but also improves the yield of Rabi in December and January. The monthly average temperature from November through March is between $18^{\circ} \mathrm{C}$ and $24^{\circ} \mathrm{C}$, which is lower than in other months. Even in April, the average temperature in the northern region is around $23^{\circ} \mathrm{C}$. These results are derived from plentiful solar radiation, which compensates for the shortcomings caused by prevailing low temperatures during these months.

(2) Area function

According to the results of Tables 3 and 4, higher real farm prices encourage farmers to cultivate more paddy fields. The area of the prior year positively or negatively influences that of the current year. In addition, the increase in precipitation expands the harvest areas of rice in most states during monsoons, which last from late May or early June to September. And during the post-monsoon period (October-December), the high precipitation reduces the harvest area of Kharif in the northern region, but enlarges the area in the eastern region. Compared with the eastern region, the rain is probably colder in the north as a result of the lowest temperature and least solar radiation during November-March. The cold rainwater tampers the harvest and diminishes the area. However, the precipitation shows a positive correlation with the area of Rabi in the late harvest season in most states. This April-July period is the hottest of the entire year. Therefore, rainfall might conceivably reduce the damage related to high temperatures.

(3) Export function, stock change function, demand

function and price linkage function

Table 5 shows that an increase in domestic rice production promotes rice exports. A high domestic real retail price of rice entices farmers to sell their rice in home markets, resulting in low exports. Regarding stock 
Table 1. Coefficients of yield of Kharif with temperature, precipitation, and solar radiation

\begin{tabular}{|c|c|c|c|c|c|c|c|c|c|c|c|c|}
\hline State & Variable & Jan & Feb & Mar & $A p r$ & May & Jun & Jul & Aug & Sep & Oct & Nov \\
\hline \multicolumn{13}{|l|}{ Northern } \\
\hline $\begin{array}{l}\text { Haryana } \\
(0.721)\end{array}$ & $\begin{array}{l}\triangle T M P \\
\triangle P R C \\
\triangle S R A\end{array}$ & & & & & & $\begin{array}{l}0.005 * * * \\
0.097 * * *\end{array}$ & $0.067 * *$ & & & & \\
\hline $\begin{array}{l}\text { Himachal Pradesh } \\
(0.611)\end{array}$ & $\begin{array}{l}\triangle T M P \\
\triangle P R C \\
\triangle S R A\end{array}$ & & & & & & & $0.000 * *$ & & $\begin{array}{l}0.076 * * \\
-0.105 * * *\end{array}$ & & \\
\hline $\begin{array}{l}\text { Jammu and } \\
\text { Kashmir } \\
(0.545)\end{array}$ & $\begin{array}{l}\triangle T M P \\
\triangle P R C \\
\triangle S R A\end{array}$ & & & & $\begin{array}{l}0.005^{* * *} \\
0.108^{*}\end{array}$ & & $0.051 * *$ & & & & & \\
\hline $\begin{array}{l}\text { Punjab } \\
(0.631)\end{array}$ & $\begin{array}{l}\triangle T M P \\
\triangle P R C \\
\triangle S R A\end{array}$ & & & $0.138 * * *$ & $-0.062 * * *$ & & $0.002 * * *$ & & & & & \\
\hline $\begin{array}{l}\text { Uttar Pradesh and } \\
\text { Uttarakhand } \\
(0.767)\end{array}$ & $\begin{array}{l}\triangle T M P \\
\triangle P R C \\
\triangle S R A\end{array}$ & & & & & & & & $-0.079 * * *$ & $\begin{array}{l}0.000 * * \\
-0.133 * * *\end{array}$ & & \\
\hline $\begin{array}{l}\text { Delhi } \\
(0.643) \\
\end{array}$ & $\begin{array}{l}\triangle T M P \\
\triangle P R C \\
\triangle S R A\end{array}$ & & & & & & & & $-0.001^{*}$ & $\begin{array}{l}-0.251 * * * \\
0.242 * * *\end{array}$ & & \\
\hline \multicolumn{13}{|l|}{ Northeastern } \\
\hline $\begin{array}{l}\text { Arunachal } \\
\text { Pradesh } \\
(0.708)\end{array}$ & $\begin{array}{l}\triangle T M P \\
\triangle P R C \\
\triangle S R A\end{array}$ & & & $0.055^{* *}$ & & & & & $0.000 * * *$ & & & $0.053^{* *}$ \\
\hline $\begin{array}{l}\text { Assam } \\
(0.504)\end{array}$ & $\begin{array}{l}\triangle T M P \\
\triangle P R C \\
\triangle S R A\end{array}$ & & & $-0.028 * * *$ & & & & & & & $-0.023^{*}$ & $-0.001 * * *$ \\
\hline $\begin{array}{l}\text { Meghalaya } \\
(0.572)\end{array}$ & $\begin{array}{l}\triangle T M P \\
\triangle P R C \\
\triangle S R A\end{array}$ & & & & & $\begin{array}{l}-0.041 * * \\
0.020 * *\end{array}$ & & & $-0.000 * * *$ & & & \\
\hline \multicolumn{13}{|l|}{ Eastern } \\
\hline $\begin{array}{l}\text { Bihar and } \\
\text { Jharkhand } \\
(0.712)\end{array}$ & $\begin{array}{l}\triangle T M P \\
\triangle P R C \\
\triangle S R A\end{array}$ & $0.440 * * *$ & & & & & & $\begin{array}{l}-0.192 * * * \\
-0.000 * *\end{array}$ & & & & \\
\hline $\begin{array}{l}\text { Manipur } \\
(0.761)\end{array}$ & $\begin{array}{l}\triangle T M P \\
\triangle P R C \\
\triangle S R A\end{array}$ & & & & & $-0.041 * * *$ & $-0.085^{*}$ & & & $0.001 * *$ & & \\
\hline $\begin{array}{l}\text { Mizoram } \\
(0.717)\end{array}$ & $\begin{array}{l}\triangle T M P \\
\triangle P R C \\
\triangle S R A\end{array}$ & & & & & $-0.084 * * *$ & & & & $-0.001 * *$ & & $0.163 * *$ \\
\hline $\begin{array}{l}\text { Nagaland } \\
(0.682)\end{array}$ & $\begin{array}{l}\triangle T M P \\
\triangle P R C \\
\triangle S R A\end{array}$ & & $-0.074 * * *$ & & & & $\begin{array}{c}0.001^{* * *} \\
-0.035^{* *}\end{array}$ & & & & & \\
\hline $\begin{array}{l}\text { Orissa (Odisha) } \\
(0.562)\end{array}$ & $\begin{array}{l}\triangle T M P \\
\triangle P R C \\
\triangle S R A\end{array}$ & & & & & & & & $0.090 * * *$ & & $\begin{array}{l}-0.254 * * * \\
0.001 * *\end{array}$ & \\
\hline $\begin{array}{l}\text { Tripura } \\
(0.588)\end{array}$ & $\begin{array}{l}\triangle T M P \\
\triangle P R C \\
\triangle S R A\end{array}$ & & & $-0.001 * * *$ & & & & & $-0.171 * * *$ & $-0.073 * * *$ & & \\
\hline $\begin{array}{l}\text { West Bengal } \\
\text { and Sikkim } \\
(0.574)\end{array}$ & $\begin{array}{l}\triangle T M P \\
\triangle P R C \\
\triangle S R A\end{array}$ & & & $\begin{array}{l}0.079 * * * \\
0.001 * *\end{array}$ & & & & $-0.068 * * *$ & & & & \\
\hline
\end{tabular}


Table 1. Coefficients of yield of Kharif with temperature, precipitation, and solar radiation (continued)

\begin{tabular}{|c|c|c|c|c|c|c|c|c|c|}
\hline State & Variable & Apr & May & Jun & Jul & Aug & Sep & Oct & Nov \\
\hline \multicolumn{10}{|l|}{ Southern } \\
\hline $\begin{array}{l}\text { Andhra Pradesh } \\
(0.662)\end{array}$ & $\begin{array}{l}\triangle T M P \\
\Delta P R C \\
\Delta S R A\end{array}$ & & & $-0.115^{* * *}$ & & & & $-0.137 * * *$ & $-0.001 * *$ \\
\hline $\begin{array}{l}\text { Karnataka } \\
(0.730) \\
\end{array}$ & $\begin{array}{l}\triangle T M P \\
\triangle P R C \\
\triangle S R A \\
\end{array}$ & & & & & & $-0.097 *$ & $\begin{array}{l}0.001 * * * \\
-0.114 * *\end{array}$ & \\
\hline $\begin{array}{l}\text { Kerala } \\
(0.631) \\
\end{array}$ & $\begin{array}{l}\triangle T M P \\
\triangle P R C \\
\triangle S R A\end{array}$ & & $0.000 * *$ & $-0.022 * *$ & & $0.053 * * *$ & & & \\
\hline $\begin{array}{l}\text { Tamil Nadu } \\
(0.502)\end{array}$ & $\begin{array}{l}\triangle T M P \\
\triangle P R C \\
\Delta S R A\end{array}$ & $0.217 * * *$ & $-0.208^{*}$ & $-0.002 * *$ & & & & & \\
\hline $\begin{array}{l}\text { Pondicherry } \\
(0.535) \\
\end{array}$ & $\begin{array}{l}\triangle T M P \\
\triangle P R C \\
\triangle S R A\end{array}$ & & & & & $\begin{array}{l}-0.247 * * * \\
0.098 * *\end{array}$ & & $-0.000 * *$ & \\
\hline \multicolumn{10}{|l|}{ Western } \\
\hline $\begin{array}{l}\text { Goa, Daman and Diu } \\
(0.641)\end{array}$ & $\begin{array}{l}\triangle T M P \\
\triangle P R C \\
\triangle S R A\end{array}$ & & & & $-0.063^{* *}$ & & $-0.150 * *$ & & $-0.005 * * *$ \\
\hline $\begin{array}{l}\text { Gujarat } \\
(0.614)\end{array}$ & $\begin{array}{l}\triangle T M P \\
\triangle P R C \\
\triangle S R A\end{array}$ & & & & $-0.180 * * *$ & & $0.000 * *$ & & $0.805 * *$ \\
\hline $\begin{array}{l}\text { Maharashtra } \\
(0.710)\end{array}$ & $\begin{array}{l}\triangle T M P \\
\triangle P R C \\
\Delta S R A\end{array}$ & & & & $-0.081 * * *$ & & $0.000 * * *$ & $-0.090 * *$ & \\
\hline $\begin{array}{l}\text { Rajasthan } \\
(0.655)\end{array}$ & $\begin{array}{l}\triangle T M P \\
\triangle P R C \\
\triangle S R A\end{array}$ & & & & $-0.169 * * *$ & & $0.002 * * *$ & $0.489^{*}$ & \\
\hline $\begin{array}{l}\text { Dadra and Nagar Haveli } \\
(0.642)\end{array}$ & $\begin{array}{l}\triangle T M P \\
\triangle P R C \\
\triangle S R A \\
\end{array}$ & & & $\begin{array}{l}-0.140 * * * \\
0.000 * \\
-0.050 * *\end{array}$ & & & & & \\
\hline \multicolumn{10}{|l|}{ Central } \\
\hline $\begin{array}{l}\text { Madhya Pradesh and } \\
\text { Chhattisgarh } \\
(0.726)\end{array}$ & $\begin{array}{l}\triangle T M P \\
\triangle P R C \\
\triangle S R A\end{array}$ & & & $0.001 * *$ & & & $-0.090 * * *$ & $-0.117 * * *$ & \\
\hline \multicolumn{10}{|l|}{ Bay of Bengal } \\
\hline $\begin{array}{l}\text { Andaman and Nicobar } \\
\text { Islands } \\
(0.467)\end{array}$ & $\begin{array}{l}\triangle T M P \\
\triangle P R C \\
\triangle S R A\end{array}$ & & & $0.000 * *$ & $-0.089 *$ & & & & $0.133 * * *$ \\
\hline
\end{tabular}

Note: *** Significant at the $1 \%$ level. ** Significant at the $5 \%$ level. * Significant at the $10 \%$ level. Numbers in parentheses are adjusted $R$-square values. $\triangle T M P, \triangle P R C$, and $\triangle S R A$ denote first-order differences in temperature, precipitation, and solar radiation, respectively. 
Table 2. Coefficients of yield of Rabi with temperature, precipitation, and solar radiation

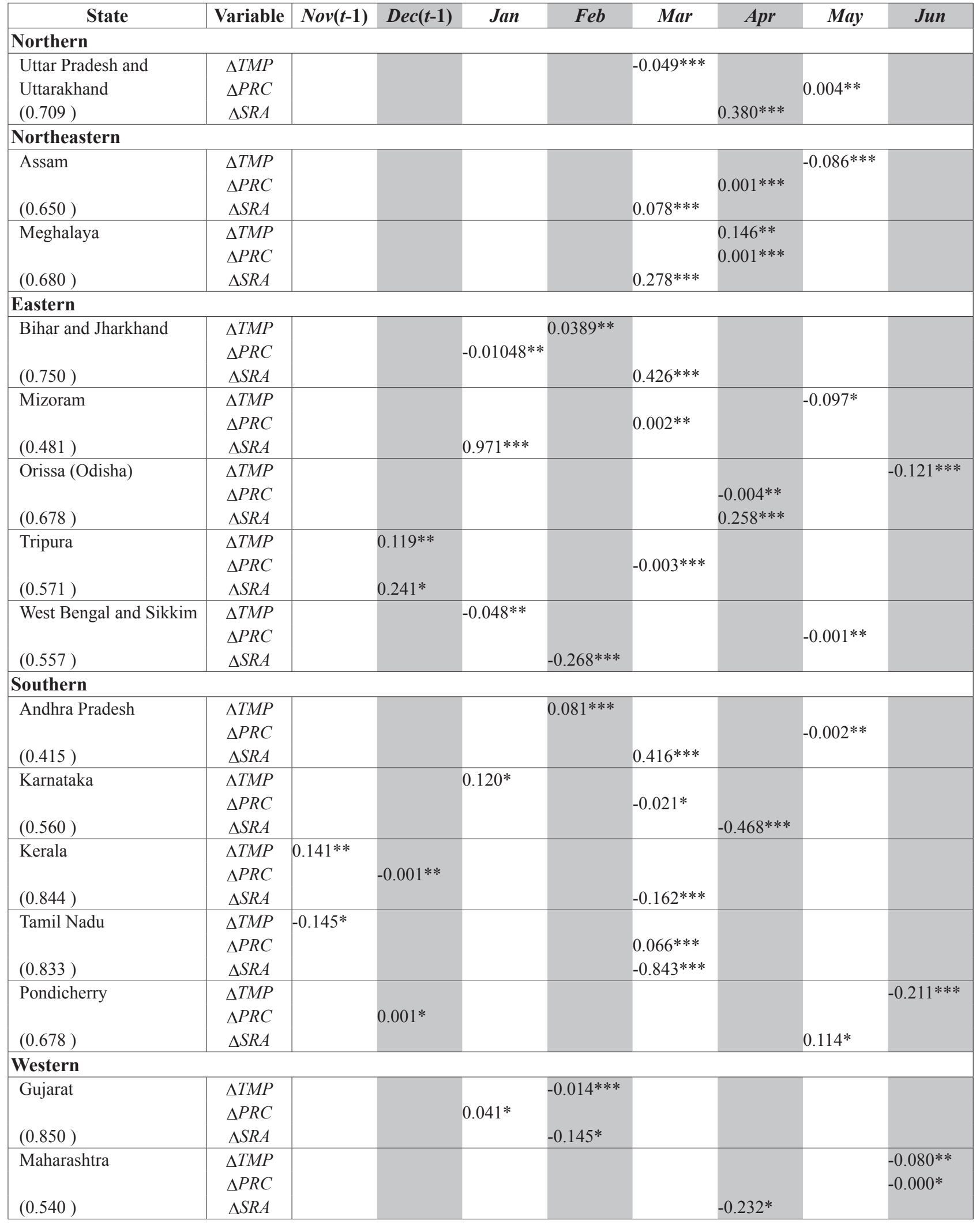

Note: *** Significant at the $1 \%$ level. ** Significant at the $5 \%$ level. * Significant at the $10 \%$ level. Numbers in parentheses are adjusted $R$-square values. $\triangle T M P, \triangle P R C$, and $\triangle S R A$ denote first-order differences in temperature, precipitation, and solar radiation, respectively. 


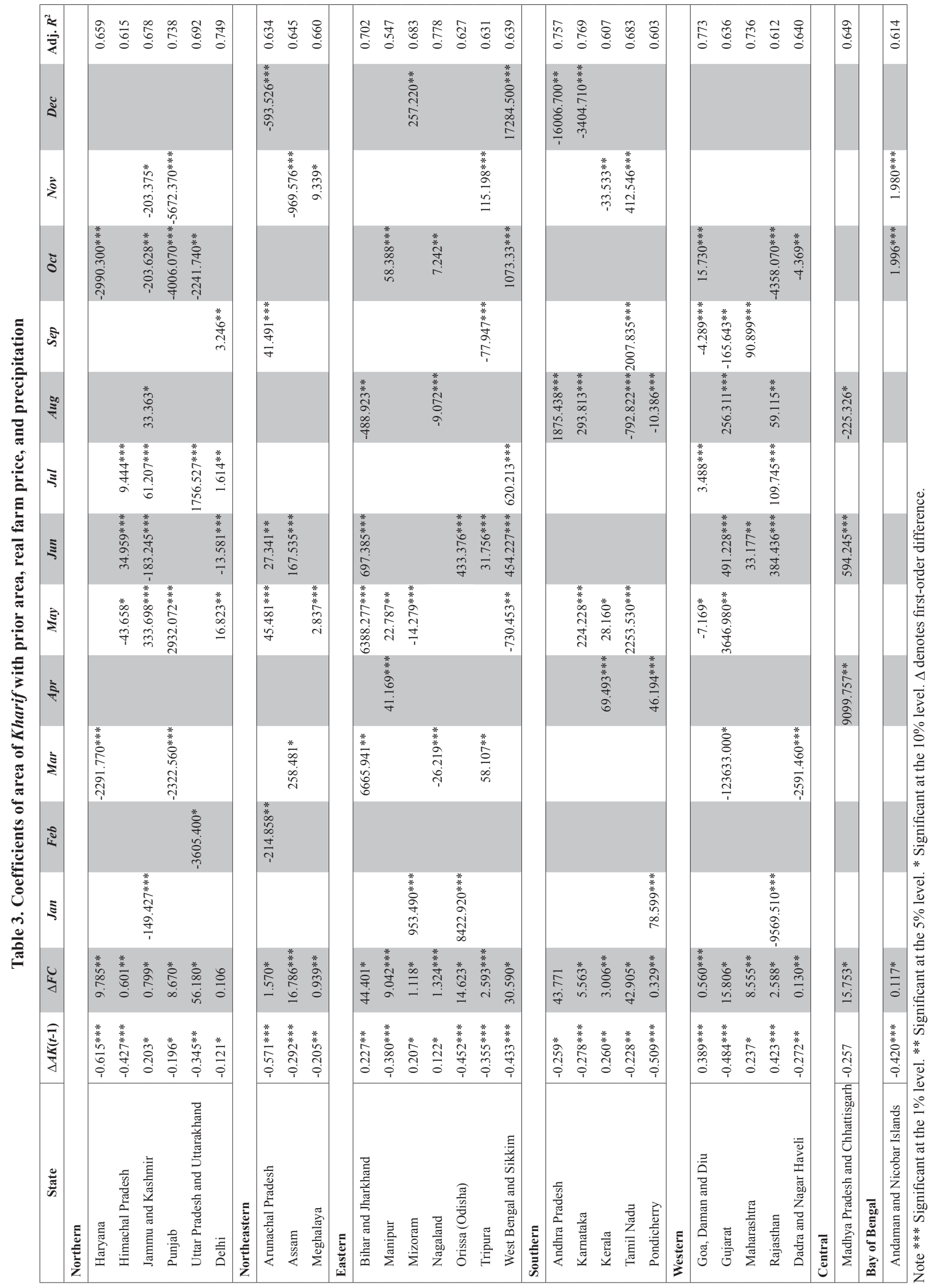




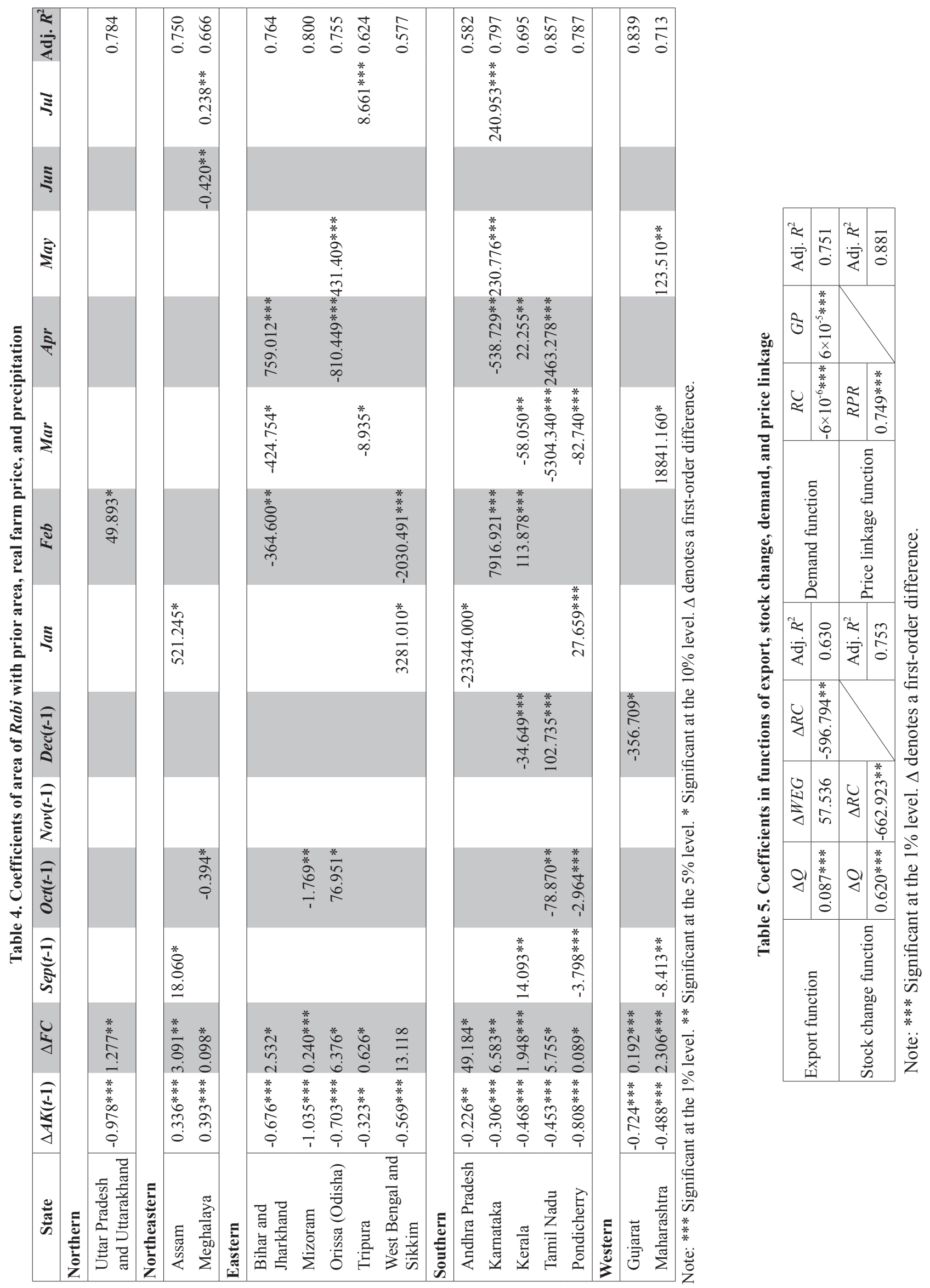


change, it is noteworthy that the stock of rice rises when the current year's rice production exceeds that of the prior year. It is conceivable that an increase in the supply of rice at an unchanged level of demand increases the inventory. Moreover, a high retail price of rice inspires farmers to sell as much rice as possible to earn higher profits. Therefore, the rice stock will decline. Table 5 also shows that the per-capita consumption of rice is related negatively to the retail price of rice and real GDP per capita. That fact suggests that high retail prices of rice deter consumers from purchasing rice. Higher real GDP per capita means that individuals have more income and wider choices for meals other than rice. The result of the price linkage function confirm a strong positive correlation between the farm price and retail price.

\section{Simulation analysis}

The NAPCC (2017) reported that the surface air temperature in India has risen by about $0.4^{\circ} \mathrm{C}$ over the past century. Regional monsoon variations have also been observed. As a major agricultural nation, climate change is a deeply important concern in India. The goal of this study is to project the future supply and demand of Indian rice under precarious climate conditions.

\section{Scenario assumptions}

The first scenario assumption is RCPs, which comprise four new pathways-RCP 8.5, RCP 6.0, RCP 4.5 and RCP 2.6 - to provide widely diverse total climate forcing (Moss et al. 2010; van Vuuren et al. 2011). Subsequently, O'Neill et al. $(2012,2014)$ introduced a set of five SSPs (SSP1, SSP2, SSP3, SSP4 and SSP5) that defines the state of human and natural societies at a macro scale. They further extended the concept by integrating climate effects and challenges to adaptation and mitigation, as presented in Figure 4. Furthermore, Hallegatte et al. (2011) demonstrated that mitigation and adaptation policies play important roles relative to reducing greenhouse gas (GHG) emissions and coping with the consequent climate change. Researchers have proposed the concept of Shared Policy Assumptions (SPAs) and incorporated it into socioeconomic pathways (Kriegler et al. 2012, 2014).

Theoretically speaking, 20 scenarios exist in the RCP-SSP combination. However, not all scenarios are likely to occur. For instance, sustainable world (SSP1) binding to very loose SPAs is unreasonable. Referring to the studies reported by Edmonds (2011), Kram (2012), and van Vuuren et al. (2014), three irrational scenarios are excluded: SSP1-RCP6.0, SSP1-RCP8.5 and SSP2RCP8.5. By eliminating the three scenarios, we then investigated the effects of futuristic climate change on Indian rice and addressed some difficulties that the government must resolve.

\section{Results}

We first explore the differences in supply and demand (per-capita consumption) among five SSP scenarios in a given RCP scenario. Figure 5 presents that, at any level of GHG emissions, SSP5 (conventional development) produces the strongest effect on production and consumption. It is conceivable that, in this pathway, high economic growth boosts the per-capita income as well as per-capita consumption. Investments in technology are very high, with a specific emphasis on increasing productivity and managing the natural environment. This progress compensates for a decreasing agricultural labor force and supports increased production. SSP1, subsequent to SSP5, implies sustainability. As with SSP5, low population is assumed for SSP1, but economic growth is slowed to

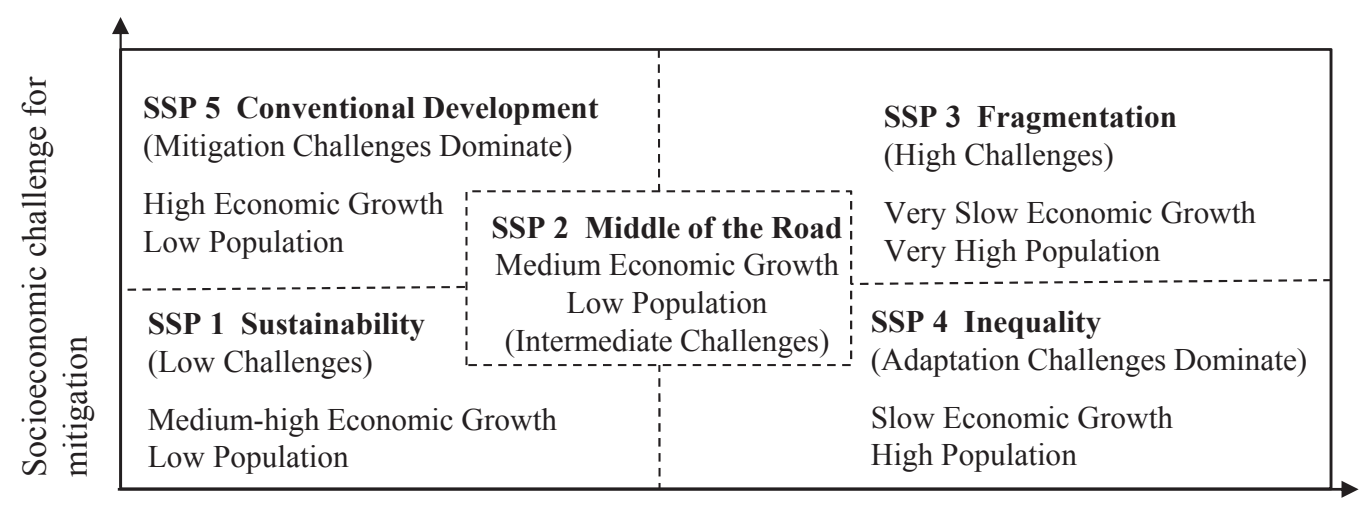

Socioeconomic challenges for adaptation

Fig. 4. Socioeconomic challenges for mitigation and adaptation (based on O'Neill et al. 2012, 2014). 
a medium-high level by the slight gap separating the rich and the poor. Similarly, the productivity of farms is elevated by improved technology, but the speed of progress is somewhat slower than that in SSP5. Therefore, production and per-capita consumption of SSP1 are located in the second place.
The moderate trends of SSP2 (middle of the road) make the incomes of individuals stable and balance concerns about advanced technology and the environment. Consequently, no extreme results are presented in these figures. SSP4 shows wide inequalities and social stratification both across and within countries.
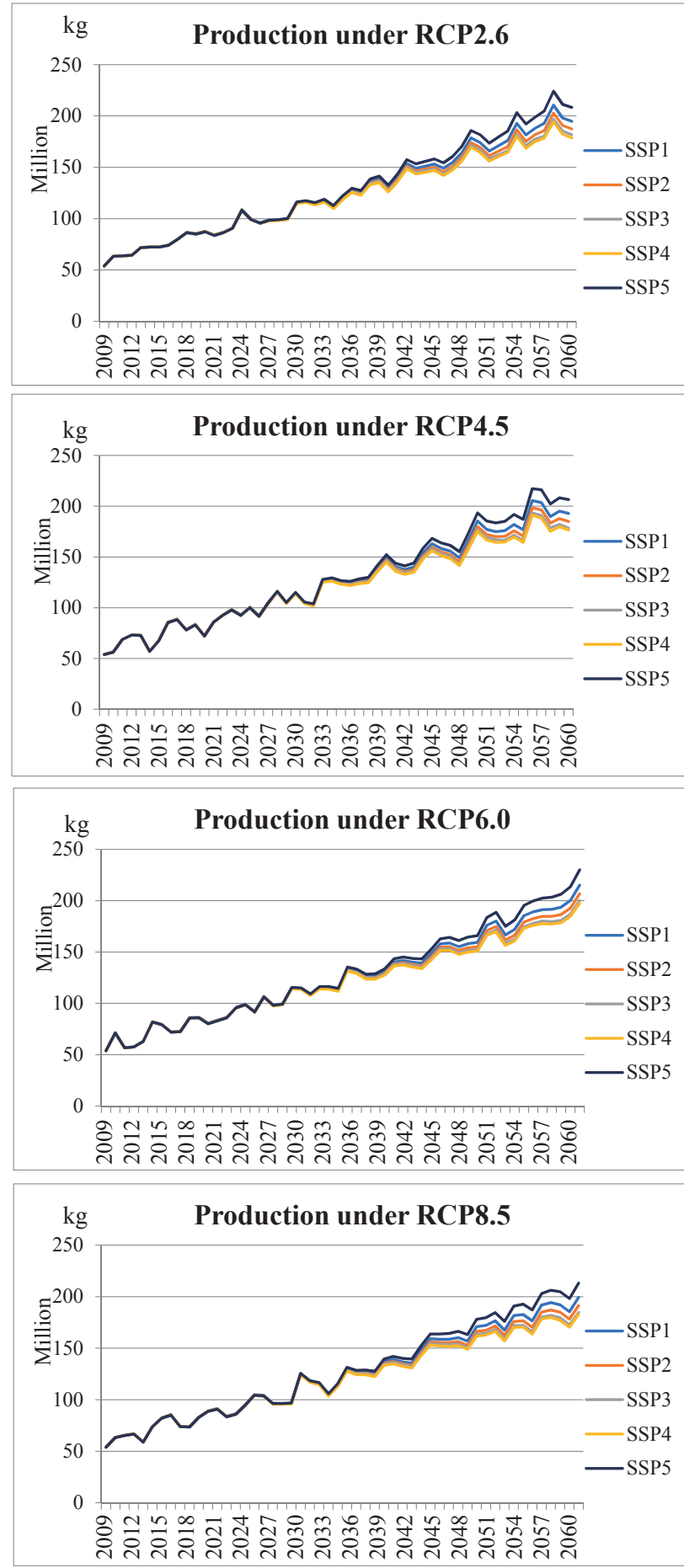
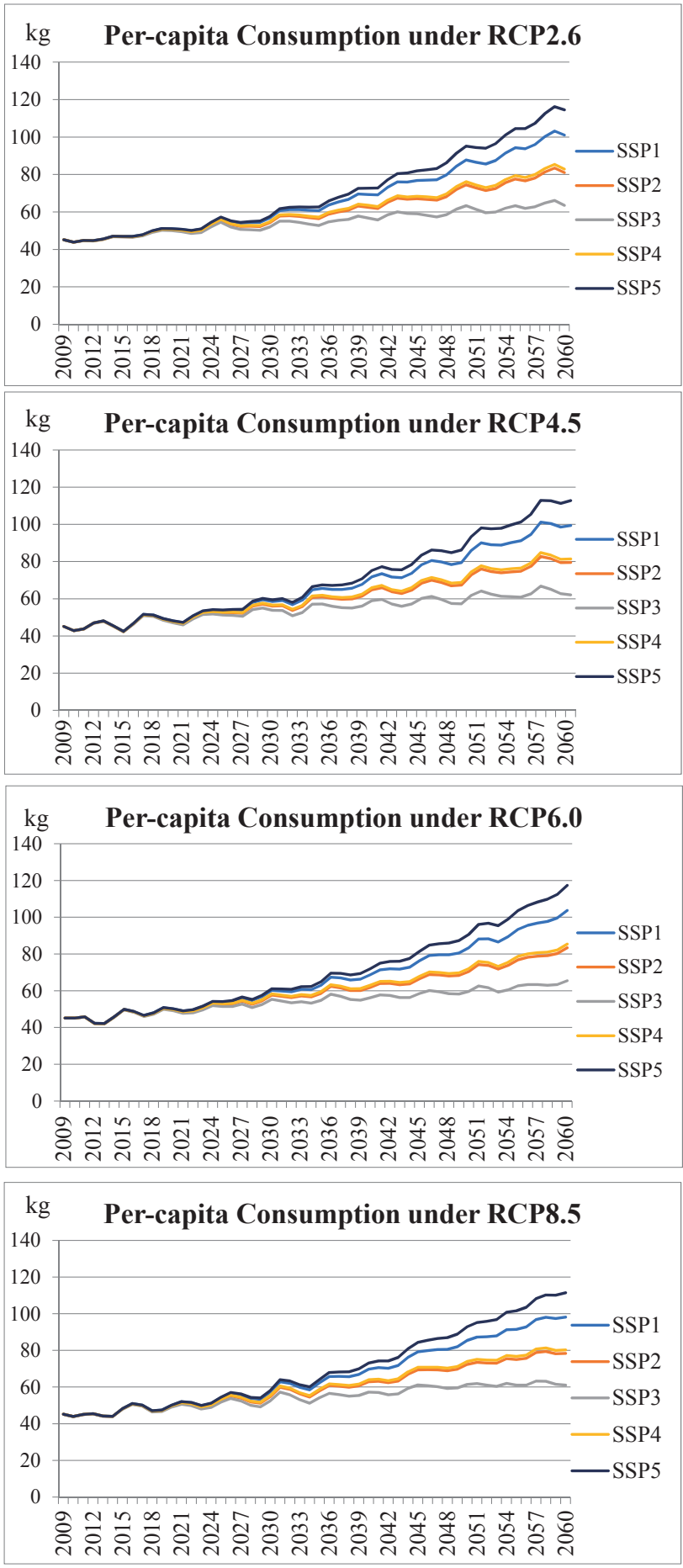

Fig. 5. Differences in production and per-capita consumption among five shared socioeconomic pathways. 
In contrast to low income people who have little consumption, high and middle-income groups have a high standard of consumption, which raises the average of per-capita consumption. However, similar situations do not occur with production. Fertile farms possessed by a few upper-class farmers have higher productivity. Nevertheless, such production cannot offset poor production at barren farms owned mostly by lower class farmers. Such production causes the lowest level of total production among the five pathways. SSP3 is defined as a fragmented world separated into regions of extreme poverty, moderate wealth, and other factors. Rivalry and conflicts among these regions impede economic and technological development, thereby resulting in deficient production. Moreover, high population growth due to poor education and a sluggish economy greatly decreases per-capita consumption. Accordingly, strengthening the capability of adaptation ameliorates the socioeconomic situation. Then it lifts the production and per-capita consumption of rice.

In the next step, we assess the influence of climate policies on yield and areas of rice under certain socioeconomic pathways. For each pathway, two probable scenarios are chosen: one with the lowest emissions is regarded as strict policies being implemented; the other with the highest emissions is regarded as lax policies being implemented. Examining the effectiveness of policies, we use a twosample $t$-test to ascertain whether two population means are equal.

Table 6 presents no difference in areas of rice regarding whether climate policies are implemented. However, strict climate policies alleviate environmental degradation and boost the yield of rice except with SSP1 and SSP2. Compared with SSP3-SSP5, SSP1 and SSP2 are assumed to have strong environmental awareness, indicating fewer challenges in terms of mitigation and adaptation. Clean technologies have been actively improved and adopted in society. Therefore, new rigid policies bring about only slight effects. In contrast, enforcing more ambitious policies in SSP3-SSP5 can lessen GHG emissions and increase rice yields.

\section{Conclusion}

Global climate change has become a crucially important issue in the last few decades. Its influence on agriculture in most countries persists as a subject of great and growing concern. India, an agricultural powerhouse, is an important target for researchers to investigate the relations between climate change and crop development. Few earlier reports of the literature describe studies that analyze this subject by state. India governs an extensive territory with diverse topography. Therefore, we are encouraged to assess how rice, the most important crop, is affected by climate change in India's respective states.

The results show that high temperatures lower the yields of rice in most states, except for states at high altitudes. Precipitation and solar radiation favor the yield of Kharif rather than that of Rabi. However, high precipitation impedes the growth of yields and rice cultivation areas during the rainy season, at a low temperature or under scant solar radiation. Increased domestic production of rice and the real world price of rice are expected to enhance rice exports. The stock of rice shows a positive correlation with the rice surplus, but it has a negative relation with the retail price of rice. Otherwise, the per-capita consumption of rice is related negatively to the retail price of rice and real GDP per

Table 6. Results of paired sample t-test for area and yield

\begin{tabular}{|c|c|c|c|c|c|c|c|c|}
\hline & & & & Yield & & & Area & \\
\hline SSP & RCP Forcing & $N$ & Mean & Variance & $t$-value & Mean & Variance & $t$-value \\
\hline \multirow{2}{*}{ SSP1 } & RCP2.6 & 51 & 3.628 & 0.718 & \multirow{2}{*}{0.816} & 51051299 & $3.48380 \mathrm{E}+13$ & \multirow{2}{*}{-0.279} \\
\hline & RCP4.5 & 51 & 3.613 & 0.727 & & 51115843 & $3.47102 \mathrm{E}+13$ & \\
\hline \multirow{2}{*}{ SSP2 } & $\mathrm{RCP} 2.6$ & 51 & 3.627 & 0.715 & \multirow{2}{*}{0.954} & 50445326 & $2.65655 \mathrm{E}+13$ & \multirow{2}{*}{0.000} \\
\hline & RCP6.0 & 51 & 3.612 & 0.691 & & 50445237 & $2.68473 \mathrm{E}+13$ & \\
\hline \multirow{2}{*}{ SSP3 } & $\mathrm{RCP} 2.6$ & 51 & 3.626 & 0.712 & \multirow{2}{*}{$2.665^{* * *}$} & 50445326 & $2.65655 \mathrm{E}+13$ & \multirow{2}{*}{-0.669} \\
\hline & RCP8.5 & 51 & 3.589 & 0.675 & & 50595331 & $2.74488 \mathrm{E}+13$ & \\
\hline \multirow{2}{*}{ SSP4 } & RCP2.6 & 51 & 3.625 & 0.711 & \multirow{2}{*}{$2.664 * * *$} & 49659705 & $1.98292 \mathrm{E}+13$ & \multirow{2}{*}{-0.676} \\
\hline & RCP8.5 & 51 & 3.588 & 0.674 & & 49812174 & $2.06319 \mathrm{E}+13$ & \\
\hline \multirow{2}{*}{ SSP5 } & RCP2.6 & 51 & 3.631 & 0.723 & \multirow{2}{*}{$2.660 * * *$} & 52207978 & $5.06516 \mathrm{E}+13$ & \multirow{2}{*}{-0.716} \\
\hline & RCP8.5 & 51 & 3.594 & 0.685 & & 52372112 & $5.21172 \mathrm{E}+13$ & \\
\hline
\end{tabular}

Note: *** Significant at the $1 \%$ level. 
capita. Furthermore, the farm prices of rice show a strong positive correlation with the retail prices of rice.

To forecast the expected production of rice up to 2060, we considered five SSPs. The results of analysis show that SSP5 (conventional development) boosts the production of rice and per-capita consumption most in India. SSP1 (sustainability) follows SSP5 according to an increase in GDP. Moreover, under future scenarios of SSPs 3-5, we found that if the Indian government does not adopt climate policies to lower GHG emissions, the rice yield will decline. Therefore, to prevent decreases in rice production, the government must not only adopt and follow aggressive climate policies but also lead society toward moderate socioeconomic pathways. Certain policies are feasible, such as on population control, the acceleration of urbanization and globalization, and technological improvement.

Finally, it is conceivable that growing and harvest seasons will be different in 2060 due to climate change. Farmers are expected to undertake actions to adapt changes. However, further investigation is necessary for which some approach (top-down, bottom-up or a combination of both) will be undertaken and for which the period of this approach will be effective. The assumptions of constant growing and harvest seasons will thus be relaxed in future studies.

\section{Acknowledgements}

This study was supported by the budget for the "Climate Change Project" of the Japan International Research Center for Agricultural Sciences (JIRCAS). We are grateful to the participants of this project, and to the two anonymous referees for their helpful comments and suggestions.

\section{Footnote}

1) The SRES scenarios were used in the Fourth Assessment Report (AR4) of the IPCC. The A1 scenario assumes high economic growth and low country borders. The A1B scenario is a balanced energy consumption scenario among the four A1 sub-scenarios. The A2 scenario assumes a block or local economy. The B1 scenario assumes progress in clean energy technology and low-country borders. The B2 scenario assumes clean energy and a localized economy. The A2 scenario is the worst case scenario. The A1B and the B2 scenarios are moderate scenarios.

\section{References}

Cabas, J. et al. (2010) Crop yield response to economic, site and climatic variables. Climatic Change, 101, 599-616.

Climatic Research Unit of the University of East Anglia (CRU) (2017) [online] http://www.cru.uea.ac.uk/ (browsed on Aug. 8, 2017).

Directorate of Economics and Statistics (2015) Agricultural Statistics at a Glance 2015. Ministry of Agriculture, Government of India. http://eands.dacnet.nic.in/PDF/ Agricultural_Statistics_At_Glance-2015.pdf

Directorate of Economics and Statistics (DES), Ministry of Agriculture and Farmers Welfare, India (2017) [online] http://eands.dacnet.nic.in/ (browsed on Aug. 8, 2017).

Directorate of Rice Development (2014) Status paper on rice. Directorate of Rice Development, Government of India.

Edmonds, J. (2011) The Role of Scenarios in Driving Climate Futures. Workshop on Climate Change Impacts and Integrated Assessment, Washington D.C., September 21, 2011.

Food and Agriculture Organization Corporate Statistical Database (FAO-STAT) (2017) [online] http://www.fao.org/ faostat/en/\#home (browsed on Aug. 8, 2017).

Furuya, J. et al. (2009) Impacts of global warming on the world food market according to SRES scenarios. World Academy of Science, Engineering and Technology, 57, 24-29.

Furuya, J. et al. (2010) Development of Supply and Demand Models of Rice in Lower Mekong River Basin Countries: REMEW-Mekong. JIRCAS Working Report, 68, 91-117.

Goswami, B. N. et al. (2006) Increasing Trend of Extreme Rain Events over India in a Warming Environment. Science, 314, 1442-1445.

Hallegatte, S. et al. (2011) Building world narratives for climate change impact, adaptation and vulnerability analyses. Nature Climate Change, 1, 151-155.

International Monetary Fund (IMF) (2017) [online] http://www.imf.org/external/np/res/commod/index.aspx (browsed on Aug. 8, 2017).

Khan, M. \& Zaman, K. (2010) Production and acreage response of wheat in north west frontier province. Sarhad Journal of Agriculture, 26, 427-433.

Kram, T. (2012) SSPs: A new framework for future scenario development. Fifth Annual IAMC Meeting, Utrecht Netherlands, November 12-13, 2012.

Kriegler, E. et al. (2012) The need for and use of socioeconomic scenarios for climate change analysis: a new approach based on shared socio-economic pathways. Global Environmental Change, 22, 807-822.

Kriegler E. et al. (2014) A new scenario framework for climate change research: the concept of shared climate policy assumptions. Climatic Change, 122, 401-414.

Kumar, K. et al. (2004) Climate impacts on Indian agriculture. International Journal of Climatology, 24, 1375-1393.

Kumar, P. et al. (2009) Demand Projections for Foodgrains in India. Agricultural Economics Research Review, 22, 237243.

Kumar, P. et al. (2011) Estimation of Demand Elasticity for Food Commodities in India. Agricultural Economics Research Review, 24, 1-14.

Kumar, P. et al. (2012) Demand and Supply of Cereals in India, 
2010-2025. IFPRI Discussion Paper, 01158.

Kumar, P. et al. (2014) Projected effect of droughts on supply, demand, and prices of crops in India. Economic and Political Weekly, 49, 54-63.

Leiserowitz, A. \& Thaker, J. (2012) Climate Change in the Indian Mind. Yale Project on Climate Change Communication, Yale University, 9-10.

Moss, R. H. et al. (2010) The next generation of scenarios for climate change research and assessment. Nature, 463, 747756.

National Action Plan on Climate Change (NAPCC), Ministry of Environment, Forest and Climate Change, Government of India (2017) [online] http://envfor.nic.in/ccd-napcc (browsed on Aug. 8, 2017).

O'Neill, B. C. et al. (2012) Meeting Report of the Workshop on The Nature and Use of New Socioeconomic Pathways for Climate Change Research. National Center for Atmospheric Research, Boulder, Colorado, November 2-4, 2011.

O’Neill, B. C. et al. (2014) A new scenario framework for climate change research: The concept of shared socioeconomic pathways. Climate Change, 122, 387-400.

Pohit, S. (1997) The impact of climate change on India's agriculture: some preliminary observations. Proceeding of the 20th International Conference of the International Association for Energy Economics, 22-24th January,
Delhi, India.

Soora, N. K. et al. (2013) An assessment of regional vulnerability of rice to climate change in India. Climate Change, 118, 683-699.

Sulser, T.B. et al. (2010) Green and blue water accounting in the Ganges and Nile basins: Implications for food and agricultural policy. Journal of Hydrology, 384, 276-291.

Tollefson, J. (2015) Is the $2{ }^{\circ} \mathrm{C}$ world a fantasy? Nature, 527, 436-438.

United Nations, World Population Prospects: The 2010 Revision (United Nations Population Division, Department of Economic and Social Affairs, New York, 2011).

van Vuuren, D. P. \& Carter, T. (2014) Climate and socioeconomic scenarios for climate change research and assessment: reconciling the new with the old. Climate Change, 122, 415-429.

van Vuuren, D. P. et al. (2011) The Representative Concentration Pathways: An Overview. Climatic Change, 109, 5-31.

von Grebmer, K. et al. (2016) 2016 Global Hunger Index: The Challenge of Hunger: Getting to Zero Hunger. Welthungerhilfe, International Food Policy Research Institute, Concern Worldwide, 47.

World Development Indicator (WDI) (2017) [online] http://data.worldbank.org/data-catalog/world-developmentindicators (browsed on Aug. 8, 2017). 
Appendix: Results of Augmented Dickey-Fuller (tau) unit root tests

Table A1. First-order differences of yield and area

\begin{tabular}{|c|c|c|c|c|c|c|c|}
\hline \multicolumn{8}{|c|}{ Kharif } \\
\hline \multirow{2}{*}{ No. } & \multirow{2}{*}{ State } & \multicolumn{2}{|c|}{$t$-value } & \multirow{2}{*}{ No. } & \multirow{2}{*}{ State } & \multicolumn{2}{|c|}{$t$-value } \\
\hline & & $\Delta Y K$ & $\Delta A K$ & & & $\Delta Y K$ & $\Delta A K$ \\
\hline 1 & Andhra Pradesh & -8.481 & -7.858 & 15 & Meghalaya & -8.243 & -7.383 \\
\hline 2 & Arunachal Pradesh & -9.570 & -10.402 & 16 & Mizoram & -5.662 & -8.342 \\
\hline 3 & Assam & -9.081 & -8.880 & 17 & Nagaland & -8.385 & -6.285 \\
\hline 4 & Bihar and Jharkhand & -8.393 & -6.231 & 18 & Odisha (Orissa) & -13.128 & -11.854 \\
\hline 5 & Goa, Daman and Diu & -9.363 & -7.450 & 19 & Punjab & -8.853 & -4.759 \\
\hline 6 & Gujarat & -11.418 & -10.858 & 20 & Rajasthan & -9.501 & -6.780 \\
\hline 7 & Haryana & -9.170 & -7.275 & 21 & Tamil Nadu & -7.755 & -7.426 \\
\hline 8 & Himachal Pradesh & -9.972 & -8.902 & 22 & Tripura & -10.661 & -9.850 \\
\hline 9 & Jammu and Kashmir & -8.719 & -8.499 & 23 & Uttar Pradesh and Uttarakhand & -11.535 & -10.630 \\
\hline 10 & Karnataka & -10.731 & -9.039 & 24 & West Bengal & -8.687 & -11.295 \\
\hline 11 & Kerala & -9.772 & -5.173 & 25 & Andaman and Nicobar Islands & -8.678 & -10.419 \\
\hline 12 & Madhya Pradesh and Chhattisgarh & -16.173 & -9.276 & 26 & Dadra and Nagar Haveli & -10.563 & -8.075 \\
\hline 13 & Maharashtra & -13.158 & -8.021 & 27 & Delhi & -6.560 & -10.799 \\
\hline 14 & Manipur & -7.706 & -7.597 & 28 & Pondicherry & -8.649 & -9.861 \\
\hline \multicolumn{8}{|c|}{ Rabi } \\
\hline \multirow{2}{*}{ No. } & \multirow{2}{*}{ State } & \multicolumn{2}{|c|}{$t$-value } & \multirow{2}{*}{ No. } & \multirow{2}{*}{ State } & \multicolumn{2}{|c|}{$t$-value } \\
\hline & & $\Delta Y R$ & $\Delta A R$ & & & $\Delta Y R$ & $\Delta A R$ \\
\hline 1 & Andhra Pradesh & -10.776 & -8.786 & 16 & Mizoram & -7.076 & -9.698 \\
\hline 3 & Assam & -8.400 & -8.338 & 18 & Odisha (Orissa) & -8.717 & -10.995 \\
\hline 4 & Bihar and Jharkhand & -8.712 & -10.685 & 21 & Tamil Nadu & -9.132 & -6.702 \\
\hline 6 & Gujarat & -9.192 & -4.224 & 22 & Tripura & -13.980 & -6.702 \\
\hline 10 & Karnataka & -6.114 & -6.709 & 23 & Uttar Pradesh and Uttarakhand & -9.137 & -6.733 \\
\hline 11 & Kerala & -10.507 & -7.261 & 24 & West Bengal & -8.142 & -7.347 \\
\hline 13 & Maharashtra & -7.922 & -10.647 & 28 & Pondicherry & -9.564 & -11.458 \\
\hline 15 & Meghalaya & -7.631 & -5.607 & & & & \\
\hline
\end{tabular}

Note: $P$-values of all variables are less than 0.01 .

Table A2. First-order differences of macro variables except STC

\begin{tabular}{|l|c|c|c|}
\hline Variable & $t$-value & Variable & $t$-value \\
\hline$\Delta F C$ & -10.339 & $\Delta W E G$ & $-4.040^{* *}$ \\
$\Delta E X P$ & -11.982 & $\Delta R C$ & -5.646 \\
$\Delta Q$ & -10.691 & $S T C$ & -9.848 \\
\hline
\end{tabular}

Note: The $p$-value of $\triangle W E G$ is $0.01-0.05$; the remaining variables have $p$-values less than 0.01 . 
Table A3. First-order differences of temperature, precipitation, and solar radiation

\begin{tabular}{|c|c|c|c|c|c|c|c|c|c|}
\hline $\bar{\Delta} \triangle T M P$ & $t$-value & $\triangle P P R C$ & $t$-value & $\triangle P R C$ & $t$-value & $\overline{D P R C}$ & $t$-value & $\triangle \triangle S R A$ & $t$-value \\
\hline 1/ Feb & -11.63 & 1/ Feb & -11.63 & 10/Apr & -10.09 & 20/Aug & -10.86 & 1/ Jun & -7.49 \\
\hline $1 /$ Oct & -11.74 & 1/ Aug & -11.62 & 10/ Aug & -14.87 & 20/ Jan & -11.07 & 1/ Mar & -11.82 \\
\hline 2/ Nov & -11.66 & 1/ Dec & -9.17 & 10/ Dec & -9.59 & 20/ Jul & -9.78 & 2/ Mar & -10.45 \\
\hline 3/ Mar & -10.92 & 1/ May & -11.81 & $10 / \mathrm{Feb}$ & -10.24 & 20/Jun & -10.47 & 3/ Mar & -10.87 \\
\hline 3/ May & -8.42 & 1/ Nov & -8.43 & 10/ Jul & -7.18 & 20/ Oct & -10.56 & 3/ Oct & -17.28 \\
\hline 4/ Feb & -9.63 & 1/ Oct & -7.92 & 10/ Mar & -9.79 & 20/ Sep & -9.83 & 4/ Jan & -9.79 \\
\hline 4/ Jul & -8.55 & 2/ Aug & -10.31 & 10/ May & -12.57 & 21/Apr & -10.07 & 4/ Mar & -10.15 \\
\hline 5/ Sep & -12.51 & 2/ Dec & -17.81 & $10 /$ Oct & -12.69 & 21/Aug & -10.01 & 5/ Jul & -20.96 \\
\hline 6/ Feb & -10.34 & 2/ Feb & -11.60 & 11/ Apr & -9.35 & 21/Dec & -10.10 & 6/ Feb & -10.30 \\
\hline 6/ Jul & -10.31 & 2/ Jun & -9.04 & 11/ Dec & -12.04 & 21/ Jun & -13.00 & 6/ Nov & -8.42 \\
\hline 7/ Jul & -9.94 & 2/ May & -11.48 & 11/ Feb & -9.85 & 21/Mar & -11.20 & 7/ Jun & -11.80 \\
\hline 8/ Sep & -12.20 & 2/ Sep & -11.31 & 11/ Mar & -10.82 & 21/ May & -11.82 & 8/ Sep & -12.53 \\
\hline 9/ Jun & -10.57 & 3/ Apr & -9.24 & 11/ May & -9.93 & 21/ Nov & -8.05 & 9/Apr & -9.78 \\
\hline 10/ Jan & -9.69 & 3/ Jan & -9.95 & 11/ Nov & -9.06 & 21/ Oct & -8.32 & 10/Apr & -9.03 \\
\hline 10/ Sep & -11.27 & 3/ Jun & -9.05 & 11/ Sep & -9.30 & 21/ Sep & -7.31 & 10/ Oct & -9.84 \\
\hline 11/ Jun & -9.21 & 3/ Mar & -11.42 & 12/ Apr & -8.49 & 22/ Jul & -9.02 & 11/ Aug & -11.84 \\
\hline 11/ Sep & -9.58 & 3/ Nov & -10.93 & 12/ Aug & -11.21 & 22/ Jun & -11.97 & 11/ Mar & -17.66 \\
\hline $12 / \mathrm{Oct}$ & -8.79 & 3/ Sep & -12.52 & 12/ Jun & -8.22 & 22/ Mar & -12.09 & 12/ Sep & -9.98 \\
\hline 13/ Jun & -10.36 & 4/ Apr & -11.12 & 13/ Jun & -9.47 & 22/ Nov & -13.33 & 13/Apr & -9.87 \\
\hline 13/ Oct & -8.85 & 4/ Aug & -10.96 & 13/ Mar & -7.27 & 22/ Sep & -10.25 & 13/ Jul & -13.69 \\
\hline 14/ Jun & -9.42 & 4/ Feb & -14.61 & 13/ May & -10.98 & 23/ Feb & -14.67 & 14/ May & -9.54 \\
\hline 15/ Apr & -8.80 & 4/ Jan & -10.54 & 13/ Sep & -12.81 & 23/ Jul & -9.93 & 15/ Mar & -11.51 \\
\hline 15/ May & -7.87 & 4/ Jul & -9.82 & 14/ Apr & -10.64 & 23/ May & -10.31 & 15/ May & -9.32 \\
\hline 16/ May & -8.82 & 4/ Jun & -11.49 & 14/ May & -11.05 & 23/ Oct & -12.48 & 16/ Jan & -9.92 \\
\hline $17 / \mathrm{Feb}$ & -9.56 & 4/ Mar & -11.00 & 14/ Oct & -9.41 & 23/ Sep & -10.84 & 16/ Nov & -9.68 \\
\hline 18/ Jun & -11.07 & 4/ May & -9.80 & 14/ Sep & -11.10 & 24/ Apr & -9.28 & 17/ Jun & -13.95 \\
\hline 18/ Oct & -9.16 & $5 / \mathrm{Jul}$ & -9.16 & 15/Apr & -10.77 & 24/ Aug & -10.97 & 18/ Apr & -7.23 \\
\hline 19/ Apr & -9.77 & 5/ May & -9.52 & 15/ Aug & -9.08 & 24/ Dec & -10.67 & 18/ Aug & -12.17 \\
\hline 20/ Jul & -11.75 & 5/ Nov & -8.95 & $15 / \mathrm{Jul}$ & -8.77 & 24/ Feb & -9.75 & 19/ Mar & -13.70 \\
\hline 21/Apr & -11.61 & 5/ Oct & -7.97 & 15/ Jun & -9.16 & 24/ Jan & -11.28 & 20/ Oct & -9.33 \\
\hline 21/ Nov & -8.96 & 5/ Sep & -10.89 & 15/ May & -10.54 & 24/ Jul & -10.16 & 21/Mar & -9.68 \\
\hline 22/ Aug & -9.40 & 6/ Aug & -9.86 & 15/ Nov & -11.76 & 24/ Jun & -9.69 & 21/ May & -7.55 \\
\hline 22/ Dec & -8.55 & 6/ Dec & -11.30 & $15 /$ Oct & -10.42 & 24/ Mar & -10.16 & 22/ Dec & -9.27 \\
\hline 23/ Aug & -11.26 & 6/ Jan & -8.17 & 16/ Dec & -11.66 & 24/ May & -11.32 & 22/ Sep & -10.54 \\
\hline 23/ Mar & -11.36 & 6/ Jun & -9.95 & 16/ Jan & -14.53 & 24/ Oct & -8.42 & 23/Apr & -11.32 \\
\hline 24/ Jan & -10.69 & 6/ Mar & -7.34 & 16/Mar & -12.15 & 25/ Jun & -9.13 & 23/ Sep & -10.74 \\
\hline 24/Mar & -10.41 & 6/ May & -10.20 & 16/ May & -9.32 & 25/ Nov & -10.51 & 24/ Feb & -8.79 \\
\hline 25/ Jul & -8.64 & 6/ Sep & -12.86 & 16/ Oct & -8.69 & $25 /$ Oct & -10.78 & 24/ Jul & -10.94 \\
\hline 26/ Jun & -11.44 & 7/ Jun & -9.54 & 16/ Sep & -11.46 & 26/ Jun & -10.22 & 25/ Nov & -8.62 \\
\hline 27/Sep & -8.49 & 7/ Mar & -9.35 & 17/ Aug & -7.76 & 26/ Mar & -7.45 & 26/ Jul & -13.56 \\
\hline 28/ Aug & -11.00 & 7/ Oct & -11.42 & $17 /$ Jun & -11.50 & 26/ Oct & -11.47 & 27/ Sep & -12.36 \\
\hline \multirow[t]{12}{*}{ 28/ Jun } & -9.04 & 8/ Jul & -11.32 & 17/ Mar & -10.96 & 27/ Aug & -11.28 & 28/ Aug & -7.46 \\
\hline & & 8/ Jun & -10.13 & $17 /$ Oct & -9.77 & $27 / \mathrm{Jul}$ & -11.73 & 28/ May & -8.83 \\
\hline & & 8/ May & -10.36 & 18/ Apr & -9.91 & 27/ Jun & -9.13 & & \\
\hline & & 9/ Apr & -9.73 & 18/ Jan & -13.39 & 27/ May & -8.13 & & \\
\hline & & 9/ Aug & -11.23 & 18/Jun & -8.47 & 27/ Sep & -11.32 & & \\
\hline & & 9/ Jan & -10.64 & 18/ May & -9.64 & 28/ Apr & -9.88 & & \\
\hline & & 9/ Jul & -11.80 & $18 /$ Oct & -10.77 & 28/ Aug & -10.50 & & \\
\hline & & 9/ Jun & -9.85 & 19/Jun & -9.85 & 28/ Dec & -9.98 & & \\
\hline & & 9/ May & -17.16 & 19/ Mar & -9.52 & 28/ Jan & -9.78 & & \\
\hline & & 9/ Nov & -10.80 & 19/ May & -9.73 & 28/ Mar & -10.46 & & \\
\hline & & 9/ Oct & -13.23 & 19/ Nov & -11.76 & 28/ Oct & -8.54 & & \\
\hline & & & & 19/ Oct & -11.60 & 28/ Sep & -8.52 & & \\
\hline
\end{tabular}

Note: Variables of climate are presented as state/month; $p$-values of all variables are less than 0.01 . 